\title{
PENERAPAN MODEL PEMBELAJARAN LEARNING CYCLE 5E UNTUK MENINGKATKAN HASIL BELAJAR MATEMATIKA SISWA KELAS VIII SMPN 15 KOTA BENGKULU
}

\author{
Rahmania Budiman $^{1}$, Rusdi ${ }^{2}$, Effie Efrida Muchlis3 ${ }^{3}$ \\ ${ }^{1}$ Program Studi Pendidikan Matematika, ${ }^{2}$ FKIP, ${ }^{3}$ Universitas Bengkulu \\ email : ${ }^{1}$ rahmania.budiman18@gmail.com, ${ }^{2}$ rusdipendmat12@gmail.com, ${ }^{3}$ effie_efrida@unib.ac.id
}

\begin{abstract}
Abstrak
Tujuan penelitian ini adalah untuk mengetahui bagaimana penerapan model learning cycle $5 E$ sehingga dapat meningkatkan hasil belajar matematika siswa kelas VIII SMPN 15 Kota Bengkulu. Penelitian ini adalah Penelitian Tindakan Kelas (PTK). Penelitian dilakukan dalam tiga siklus dengan alur penelitian yaitu Perencanaan Tindakan, Pelaksanaan Tindakan, Observasi (Pengamatan), dan Refleksi. Subjek penelitian ini adalah siswa kelas VIII F SMP Negeri 15 Kota Bengkulu tahun ajaran 2017/2018 yang berjumlah 29 orang, dengan siswa laki-laki berjumlah 17 orang dan siswa perempuan berjumlah 12 orang. Pengumpulan data melalui tes hasil belajar. Berdasarkan hasil penelitian dan pembahasan, diperoleh kesimpulan bahwa model Learning Cycle 5E dapat meningkatkan hasil belajar matematika siswa. Hasil belajar siswa pada siklus I ditunjukan dengan nilai rata-rata 65,3 dengan ketuntasan belajar klasikal 48,3\%. Pada siklus II, nilai rata-rata siswa adalah 71,9 dengan ketuntasan belajar klasikal sebesar 63,4\%. Padasiklus III nilai rata-rata siswa adalah 79,7 dengan ketuntasan belajar klasikal sebesar $82,7 \%$.
\end{abstract}

Kata kunci : Model Pembelajaran Cycle Learning 5E, Hasil belajar matematika

\section{Abstract}

The purpose of this study to knowing how the application of models of learning cycle 5E so as to improve learning outcomes math class VIII SMPN 15 Bengkulu city. This research is aclassroom action research (PTK). The study was conducted in three cycles withgrooves research is Action Planning, Implementation Measures, Observation(Observation), and Reflections. The subjects were students of class VIII F SMPNegeri 15 Bengkulu City academic year 2017/2018 which amounted to 29 people,with male students numbered 17 people and women students numbered 12 people. Data collected by result of learning. Based on the analysis results of research and discussion, we concluded that the model Learning Cycle 5E can increase the activity and results of students' mathematics learning. Student learning outcomes in the first cycle is shown by the average value of 65,3 with 48,3\% classical learningcompleteness. In the second cycle, the average value was 71,9 students withclassical learning completeness amounted to 63,4\%. In the third cycle students'average score was 79,7 with classical learning completeness amounted to $82,7 \%$.

Keywords : Cycle Learning 5E, Mathematics learning results

\section{PENDAHULUAN}

Matematika merupakan salah satu mata pelajaran yang menduduki peranan penting dalam pendidikan dan kehidupan masyarakat. Oleh karena itu, matematika perlu diajarkan pada semua jenjang pendidikan, mulai dari sekolah dasar sampai perguruan tinggi. Dalam pelajaran matematika khususnya pada tingkat sekolah, diperlukan prinsip belajar yang sesuai dan pemahaman konsep yang benar. Hal tersebut diperlukan agar siswa dapat memahami materi-materi yang diajarkan serta mampu mengaplikasikan ilmu matematika yang didapat dalam kehidupan sehari-hari. 
Sebagian besar siswa menganggap matematika sebagai mata pelajaran yang rumit dan sulit dipahami, sehingga seringkali menjadi momok yang menakutkan bagi siswa. Hal ini terjadi karena untuk mempelajari matematika diperlukan kegiatan berpikir yang tinggi dan proses pembelajaran yang saat ini masih didominasi oleh guru.

Berdasarkan hasil wawancara dengan salah satu guru mata pelajaran matematika yaitu ibu Dra. Murlina diperoleh bahwa masih ada siswa yang mendapatkan nilai dibawah standar ketuntasan. Nilai rata-rata hasil belajar siswa tahun pelajaran 2017-2018 hanya mencapai 60,11 dari kriteria ketuntasan minimum yang ditetapkan sekolah yaitu 70. Hasil observasi terhadap proses pembelajaran di kelas ditemukan bahwa : (a) partisipasi dan keaktifan siswa masih kurang optimal, ini terlihat dari guru lebih banyak memberikan penjelasan tentang materi yang akan dipelajari, sementara siswa cenderung pasif mendengarkan, menyimak dan mencatat apa saja yang disampaiakan oleh guru bahkan ada juga sibuk sendiri dengan kegiatannya, sehingga proses pembelajaran hanya berpusat kepada guru. (b) Kerjasama dalam kelompok juga jarang diterapkan sehingga menyebabkan aktifitas belajar siswa masih rendah. (c) Siswa cenderung menghafal tanpa memahami dengan baik materi yang disampaikan guru sehingga menyebabkan rendahnya pemahaman dan hasil belajar siswa.

Pembelajaran matematika hendaknya disampaikan dengan suatu model pembelajaran yang bervariasi. Salah satu model pembelajaran yang dapat digunakan yaitu model pembelajaran learning cycle 5E. Learning Cycle 5E adalah salah satu model pembelajaran yang berpusat pada siswa. Sehingga siswa berperan aktif untuk dapat menguasai kompetensi-kompetensi yang harus dicapai dalam tujuan pembelajaran (Lestari \& Yudhanegara, 2015:55-56). Keunggulan learning cycle $5 E$ terletak pada teknik pembelajaran yang banyak melibatkan siswa dalam prosesnya. Melalui penerapan model pembelajaran cycle learning $5 E$ siswa melakukan berbagai aktivitas pembelajaran dengan langkah-langkah sebagai berikut yaitu : (1) engagement, (2) exploration, explanation, (4) elaboration, dan (5) evaluation. Sehingga meningkatnya hasil belajar siswa.

Rumusan masalah dalam penelitian ini yaitu bagaimana cara penerapan model pembelajaran learning cycle $5 E$ agar dapat meningkatkan hasil belajar siswa di kelas VIII SMP Negeri 15 Kota Bengkulu?. Tujuan pembelajaran dalam penelitian ini adalah mengetahui cara penerapan model pembelajaran learning cycle $5 E$ agar dapat meningkatkan hasil belajar siswa di kelas VIII SMP Negeri 15 Kota Bengkulu.

Lestari \& Yudhanegara (2015:55-56) berpendapat bahwa cycle learning adalah suatu model pembelajaran yang berpusat pada siswa. Siklus yang dimaksud yaitu rangkaian tahapan kegiatan yang diorganisir sedemikian rupa sehingga siswa berperan aktif untuk dapat menguasai kompetensi-kompetensi yang harus dicapai dalam tujuan pembelajaran. Sedangkan menurut (Hardini \& Puspitasari, 2012:137) cycle learning (pembelajaran siklus) adalah salah satu model pembelajaran dengan pendekatan konstruktivis yang pada mulanya terdiri dari 3 tahap yaitu eksplorasi, pengenalan konsep, dan penerapan konsep. Penerapan konsep dapat meningkatkan pemahaman konsep dan motivasi belajar siswa, karena mereka mengetahui penerapan nyata dari konsep yang telah pelajari.

\section{Langkah-Langkah Pembelajaran Learning cycle $5 E$}

Huda (2012:56) menyebutkan bahwa sintaks model pembelajaran cycle learning dibagi menjadi 4 tahapan yaitu sebagai berikut:

1. Mengalami, yaitu menegaskan bahwa siswa seharusnya terlibat aktif mengeksplorasi pengalaman belajar jika mereka ingin mendapatkan hasil yang terbaik. Hal ini bisa dilakukan dengan merumuskan pertanyaan-pertanyaan yang tepat.

2. Refleksi, meliputi usaha kembali menghayati tugas dan mereview apa yang

Penerapan Model Pembelajaran Learning Cycle 5e Untuk Meningkatkan Hasil Belajar Matematika Siswa Kelas VIII SMPN 15 Kota Bengkulu 
sudah dilakukan dan dialami. Pada tahap ini, siswa dan guru harus merefleksikan apa yang telah mereka pelajari, dan bagaimana mereka mempelajarinya sehingga nantinya dapat menimbulkan pembelajaran yang lebih baik lagi.

3. Interpretasi, adalah berusaha menghubungkan pengalaman belajar yang sebenarnya dengan teori-teori yang mendeskripsikan dengan pemahaman yang lebih luas tentang teori-teori tersebut, yang melibatkan guru dan siswa sehingga terbukti bahwa diskusi memang sangat berguna dalam pembelajaran.

4. Prediksi, siswa dilibatkan dalam merencanakan pengalaman belajar untuk memperoleh pemahaman baru tentang apa yang terjadi selanjutnya atau tindakan apa yang seharusnya diambil untuk mengerjakan tugas dengan baik.

Sedangkan menurut Lestari \& Yudhanegara (2015:56-57) mengatakan bahwa tahapan model pembelajaran cycle learning terdiri dari 5 fase yaitu, sebagai berikut : (1) Engagement yaitu guru berusaha membangkitkan minat dan keingintahuan siswa tentang materi yang akan dipelajari dengan kehidupan sehari-hari dengan menyiapkan atau mengkondisikan siswa untuk belajar serta melakukan tanya jawab dalam mengeksplorasi pengetahuan awal siswa. (2) Exploration yaitu siswa di bentuk kelompok-kelompok kecil antara 2-4 siswa untuk bekerja sama tanpa pembelajaran langsung dari guru dan memungkinkan siswa membangun pengetahuan sendiri. Dalam hal ini guru harus benar-benar merancang proses pembelajaran yang akan dilakukan dengan baik dan guru sebagai fasilitator serta motivator dengan tujuan tahap ini adalah mengecek pengetahuan yang dimiliki siswa apakah sudah benar, masih salah, atau mungkin sebagian benar sebagian salah. (3) Explanation yaitu guru meminta siswa untuk mengungkapkan atau menjelaskan suatu konsep yang telah mereka dapatkan dengan kalimat sendiri, sedangkan siswa lain mendengarkan dan menanggapi penjelasan dari siswa tersebut. (4) Elaboration yaitu siswa memperluas konsep yang telah dipelajari dengan mengaplikasikan pemahaman mereka mengenai konsep yang didapatkan sebelumnya untuk memecahkan masalah baik secara individu maupun kelompok.(5) Evaluation yaitu siswa mengevaluasi tahapan yang telah dilaksanakan apakah sudah berjalan dengan baik atau belum dengan memberikan soal tes diakhir pelajaran untuk mengukur sejauh mana tingkat pengetahuan dan pemahaman siswa terhadap konsep yang dipelajari.

Jihad \& haris (2012:15) menyimpulkan bahwa hasil belajar adalah tingkah laku siswa secara nyata setelah dilakukan proses belajar mengajar yang sesuai dengan tujuan pembelajaran. . Gagne (dalam buku Dimyati \& Mudjiona, 2013:11-12) membagi lima kapabilitas hasil belajar yaitu : Informasi verbal, Keterampilan intelektual, Strategi kognitif, Keterampilan motorik, Sikap. Dalam sistem pembelajarn nasional, rumusan tujuan pembelajaran, baik tujuan kurikulum maupun tujuan instruksional, menggunakan klasifikasi hasil belajar dari Benyamin Bloom menjadi tiga ranah, yaitu : ranah kognitif, ranah afektif, dan ranah psikomotorik

Berdasarkan hasil pemikiran diatas, maka peneliti tertarik untuk melakukan suatu penelitian yang berjudul: "Penerapan Model Pembelajaran Learning Cycle $5 E$ Untuk Meningkatkan Hasil Belajar Matematika Siswa Kelas VIII SMP Negeri 15 Kota Bengkulu".

\section{METODE}

Jenis penelitian yang dilakukan adalah penelitian tindakan kelas (PTK). Penelitian tindakan kelas adalah penelitian yang dilakukan pada sebuah kelas untuk mengetahui akibat tindakan yang diterapkan pada suatu subyek penelitian dikelas tersebut (Trianto, 2011:13). Kunandar, (2011:41) menyebutkan penelitian tindakan kelas memiliki peranan yang sangat penting dan strategi untuk meningkatkan mutu pelajaran apabila diimplementasikan dengan baik dan benar.

Penelitian tindakan kelas (PTK) memiliki 4 tahapan penting, yaitu: (1) Perencanaan Tindakan (Planning), (2) Pelaksanaan (Action), 
(3) Pengamatan (Observation), dan (4) Refleksi (Reflection). Keempat tahapan dalam penelitian tindakan tersebut adalah unsur yang membentuk suatu siklus, dimana satu siklus merupakan satu putaran beruntun yang dimulai dari tahap penyusunan rancangan sampai dengan refleksi.

\section{Tempat dan Waktu Penelitian}

Penelitian ini dilaksanakan di SMP Negeri

15 Kota Bengkulu dan waktu penelitiannya pada bulan Maret-Mei tahun 2018 semester genap tahun ajaran 2017/2018.

\section{Subjek Penelitian}

Subjek penelitian ini adalah siswa kelas VIII F semester genap yang berjumlah 29 siswa, yang terdiri dari 17 siswa laki-laki dan 12 siswa perempuan. Pemilihan subjek ini berdasarkan wawancara bersama guru mata pelajaran matematika pada tanggal 07 Februari 2018 diketahui bahwa siswa kelas VIII.F memiliki kemampuan kognitif yang cenderung heterogen. Selain hal tersebut pemilihan subjek ini juga dikarenakan pada kelas VIII.F diketahui masih ada siswa yang memiliki nilai di bawah standar ketuntasan. Nilai rata-rata ulangan semester ganjil siswa kelas VIII.F adalah 60,11 yang masih tergolong lebih rendah dari kelas lainnya.

\section{Prosedur Penilitian}

Penelitian yang dilakukan adalah Penelitian Tindakan Kelas. Siklus penelitian ini berupa prosedur kerja dalam suatu penelitian tindakan kelas yang ditempuh secara bertahap. Penelitian tindakan kelas (PTK) memiliki 4 tahapan penting, yaitu: (1) Perencanaan Tindakan (Planning), (2) Pelaksanaan (Action), (3) Pengamatan (Observation), dan (4) Refleksi (Reflection). Keempat tahapan dalam penelitian tindakan tersebut adalah unsur yang membentuk suatu siklus, dimana satu siklus merupakan satu putaran beruntun yang dimulai dari tahap penyusunan rancangan sampai dengan refleksi.

1. Perencanaan tindakan

Pada tahap perencanaan ini peneliti mempersiapakan skenario pembelajaran yang berisikan langkah-langkah pembelajaran yang dilakukan serta menyusun perangkat pembelajaran dan instrumen, yaitu:

a. Menyusun Rencana Pelaksanaan Pembelajaran (RPP) yang berorientasi pada penerapan model pembelajaran learning cycle $5 E$.

b. Mempersiapkan lembar aktivitas siswa sebagai sarana dalam kegiatan pembelajaran

c. Mempersiapkan lembar observasi aktivitas belajar siswa yang menerapkan model pembelajaran learning cycle $5 E$

d. Mempersiapkan alat peraga yang akan digunakan untuk membantu proses pembelajaran

e. Menentukan kelompok belajar yang heterogen, baik dari kemampuan kognitif maupun jenis kelaminnya

f. Mempersiapkan soal tes akhir setiap siklus beserta rubik penilaiannya.

2. Pelaksanaan tindakan

Pada tahap pelaksanaann ini peneliti bertindak sebagai guru yang melaksanakan pembelajaran dikelas dengan penerapan model pembelajaran cycle learning. Pelaksanaannya mengacu pada rencana pelaksanaan pembelajaran (RPP).

Siklus I

a. Kegiatan Pembuka

Pada kegiatan pembuka yang dilakukan yaitu guru mengucapkan salam, meminta ketua kelas memimpin doa sebelum belajar, mengecek kehadiran siswa, guru mengkondisikan kelas agar siap untuk belajar, guru menyampaikan tujuan pembelajaran yang ingin dicapai siswa, serta memotivasi siswa untuk selalu giat belajar, guru mengkondisikan siswa untuk mengatur posisi duduk siswa sesuai dengan kelompok yang telah dibagikan

b. Kegiatan Inti

pada kegiatan inti yang dilakukan sesuai dengan tahapan model pembelajaran learning cycle $5 E$, yaitu

A. Tahapan Engagement

1. Guru memembagi LAS kepada setiap kelompok. 
2. Guru mengarahkan siswa untuk mengerjakan LAS dengan meminta memperhatikan LAS

3. Meminta mengamati alat peraga yang berada pada setiap kelompok masingmasing.

4. Menjawab pertanyaan yang ada pada tahap engagement yang dibantu dengan guru, sehingga dapat membangkitkan minat siswa serta keingintahuan siswa terhadap materi yang dipelajari.

B. Tahapan Exploration

1. Siswa bekerja sama dalam kelompok kecil tanpa pembelajaran langsung dari guru dan memungkinkan siswa membangun pengetahuan sendiri.

2. Siswa melakukan dan mencatat pengamatan serta ide-ide atau pendapat yang berkembang yang didapat dalam diskusi.

3. Siswa meminta bantuan guru jika mengalami kesulitan dalam proses pembelajaran.

C. Tahapan Explanation

1. Guru meminta perwakilan dari beberapa kelompok untuk mempresentasikan hasil diskusinya di depan kelas.

2. Guru meminta kelompok yang tidak mempresentasikan untuk memberikan pendapatnya.

3. Guru memberika penegasan kembali mengenai hasil presentasi yang disampaikan.

D. Tahapan Elaboration

1. Guru meminta siswa menerapkan konsep dan pengetahuan yang telah diperoleh pada tahapan sebelumnya.

2. Guru meminta mengerjakan soal latihan yang ada pada LAS secara kelompok dengan waktu yang telah ditentukan.

3. Guru meminta perwakilan kelompok untuk menuliskan jawaban mereka dipapan tulis.

4. Guru meminta siswa untuk mengumpulkan LAS.
E. Tahapan Evaluation

1. Siswa kembali diminta mengerjakan soal evaluasi secara individu dengan waktu yang telah ditentukan.

2. Guru meminta siswa untuk mengumpulkan LAS setelah waktu yang diselesaikan.

c. Penutup

Dalam kegiatan penutup yang dilakukan yaitu guru menyimpulkan materi yang telah dipelajari, guru memberikan informasi untuk mempelajari materi yang akan dipelajari setiap pertemuan, guru menutup pembelajaran dengan mengucap salam.

Siklus II

Siklus II diadakan jika siklus I belum memberikan hasil yang diharapkan.

Siklus III

Siklus III diadakan jika siklus II belum memberikan hasil yang diharapkan.

\section{Pengamatan (Observation)}

Observasi dilaksanakan ketika kegiatan pembelajaran berlangsung. Kegiatan tersebut harus dilaksanakann secara berencana, karena hasil yang diperoleh dari observasi ini akan memberikan petunjuk perbaikan untuk pemberian tindakan selanjutnya. Observasi dilakukan secara bersamaan dengan menggunakan lembar pengamatan siswa, karena antara tindakan dan observasi merupakan suatu kesatuan.

\section{Refleksi (Reflection)}

Pada tahap ini peneliti menganalisis dan mengulas data secara kritis, terutama yang berkaitan dengan perubahan yang terjadi pada tindakan kelas, baik pada diri siswa, suasana kelas, maupun pada diri peneliti yang dilakukan selama proses pembelajaran dan saat observasi berlangsung. Hasil refleksi digunakan untuk mengetahui apakah tindakan yang dilakukan sudah mencapai kriteria keberhasilan atau belum sehingga peneliti dapat merencanakan proses pembelajaran yang baru untuk para siswa agar mencapai tujuan pembelajaran.

\section{Instrument Penelitian}

\section{Lembar Tes Hasil Belajar Siswa}

Tes adalah alat ukur yang memiliki prosedur sistematis yang dipergunakan untuk 
mengukur dan menilai suatu pengetahuan atau penguasaan objek ukur terhadap seperangkat konten dan materi tertentu (Hamzah, 2014:100). Tes digunakan untuk mengukur sejauh mana tingkat pemahaman siswa terhadap materi pelajaran yang diajarkan. Tes disusun berdasarkan kompetensi dasar pada materi tersebut. Tes yang digunakan berupa tes akhir (post-test) setiap siklus. Tes akhir setiap siklus digunakan untuk memperoleh data tentang hasil belajar dan tingkat penguasaan konsep disetiap siklus. Tes dilakukan secara individu.

\section{Teknik Pengumpulan Data}

\section{Tes Hasil Belajar Siswa}

Tes hasil belajar yang diperoleh dari setiap siklus, dianalisis secara deskriptif untuk mengetahui nilai rata-rata hasil belajar dan persentase ketuntasan belajar.

\section{A. Nilai Rata-rata Hasil Belajar}

Nilai rata-rata hasil belajar setiap siswa diperoleh dari nilai tes setiap siklus. Adapun nilai rata-rata hasil belajar siswa dihitung sebagai berikut :

$$
\overline{\boldsymbol{X}}=\frac{\sum x}{N}
$$

(Sudjana, 2009:109)

Keterangan :

$$
\begin{aligned}
& \bar{X}=\text { Nilai rata-rata } \\
& \sum x=\text { jumlah nilai akhir siswa } \\
& N=\text { jumlah subjek }
\end{aligned}
$$

\section{B. Presentasi Ketuntasan Belajar}

Berdasarkan kurikulum 2013 di SMP Negeri 15 Kota Bengkulu menyatakan ketuntasan belajar untuk (a) individu : jika siswa mendapat nilai $\geq 70$, (b) klasikal: jika $75 \%$ siswa mendapat nilai $\geq 70$. Persentase ketuntasan belajar klasikal dihitung dengan menggunakan persamaan :

$$
p=\frac{\sum \text { siswa yang tuntas belajar }}{\sum \text { seluruh siswa }} \times 100 \%
$$

Keterangan :

$\mathrm{p}=$ Ketuntasan Belajar Klasikal

\section{Indikator keberhasilan tindakan}

Ketuntasan belajar tercapai apabila siswa mendapat nilai $\geq$ KKM yaitu 70 . Berdasarkan ketuntasan belajar klasikal, dianggap tuntas jika minimal $\geq 75 \%$ mendapat nilai $\geq 70$.

\section{HASIL DAN PEMBAHASAN}

\section{A. HASIL}

\section{Hasil Belajar Matematika Siklus I}

Pelaksanaan pada siklus I terlihat bahwa siswa masih susah untuk menyesuaikan diri dengan model pembelajaran learning cycle $5 E$ ini terlihat dari Sebanyak 15 orang siswa sudah mendengarkan dan memperhatikan penjelasan guru dengan baik dan 14 orang siswa masih sibuk dengan kegiatan masing-masing walaupun sudah berkurang seperti tidak adanya siswa bermain hp saat jam pembelajaran

Pembelajaran tidak lagi berpusat kepada guru. Guru tidak lagi menjelaskan materi secara keseluruhan melainkan siswa yang mencari tahu tentang materi yang dipelajari dengan berbantuan guru sehingga siswa yang terlibat aktif, terlihat dari aktivitas yang dilakukan siswa, namun masih perlu perbaikan karena siswa yang aktif belum maksimal hanya 1-2 orang dalam setiap kelompok yang aktif.

Secara keseluruhan terdapat sebanyak 2 kelompok saja yang sudah terbiasa berdiskusi. Awalnya hanya 1 kelompok yang berdiskusi untuk pertemuan pertama dan kedua, kemudian untuk pertemuan ketiga dan kempat terdapat 2 kelompok yang begitu antusias dalam menyelesaikan tugas yang diberikan secara kelompok. Sedangkan 5 kelompok lainnya masih mengandalkan 1-2 anggota dalam kelompok untuk mengerjakan tugas.

Guru menggunakan model pembelajaran cycle learning $5 E$ dalam proses pembelajaran. sebanyak 10 orang siswa sudah tidak menghafal materi tetapi mereka memahi setiap proses pembelajaran sehingga mereka dapat menyimpulkan sendiri materi yang mereka dapatkan.

Hasil belajar yang diperoleh dari 29 orang siswa yang mengikuti tes, sebanyak 12 siswa memenuhi KKM. Rata-rata kelas yang diperoleh siswa adalah 65,3 dengan ketuntasan belajar $48,3 \%$.

\section{Hasil Belajar Matematika Siklus II}

Siklus II siswa sudah mulai terbiasa denagn model pembelajaran learning cycle $5 E$, 
sehingga siswa dapat mengikuti pembelajaran dengan baik, sehingga hasil pembelajaran meningkat. Terlihat dari 17 orang siswa sudah mendengarkan, memperhatikan guru dengan baik dan 12 orang siswa memberikan tanggapan terhadapan pertanyaan yang diberikan serta meningkatnya minat dan rasa ingin tahu siswa.

Setelah itu sebanyak 4 kelompok telah bekerja sama dalam diskusi, tetapi untuk 3 kelompok lain sudah ada kerja sama anatara satu anggota dengan anggota lainnya.

Terdiri 4 kelompok yang berani untuk mempresentasikan hasilnya, kemudian siswa juga mulai memberikan tanggapan jika ada kesalahan. Sebanyak 4 kelompok yang tidak lagi kebingungan, tetapi ada kelompok yang kurang teliti dalam operasi perhitungan dan satuan pada jawaban.

Hasil belajar yang diperoleh dari 29 orang siswa yang mengikuti tes, sebanyak 18 siswa memenuhi KKM. Rata-rata kelas yang diperoleh siswa meningkat menjadi 71,9 dengan ketuntasan belajar klasikal 63,4\%.

\section{Hasil Belajar Matematika Siklus III}

Pelaksanaan pada siklus III terlihat bahwa hasil belajar siswa semakin meningkat. Terlihat dari 25 orang siswa telah mendengarkan, memperhatikan guru dengan baik saat menjelaskan, sebanyak 20 orang telah memberikan tanggapan terhadapan pertanyaan yang diberikan guru, sehingga meningkatnya minat dan rasa ingin tahu siswa.

Sebanyak 6 kelompok telah bekerja sama dalam diskusi dan 5 kelompok yang berani untuk mempresentasikan hasilnya, tetapi karena untuk mempersingkat waktu guru memberikan 1 kelompok untuk mempresentasikannya. dan itu kelompok yang tidak pernah menunjuk saat dipresentasi serta sebanyak 6 kelompok yang telah mengaplikasikan materi dengan baik dan berani untk menuliskan hasilnya dipapan tulis.

Terlihat juga sebanyak 24 orang siswa yang bersungguh-sungguh dalam mengerjakan soal. Dan sisanya sudah ada yang dikerjkan walaupun siswa sambil mengobrol seperti melamun, mengobrol sehingga nilai rata-rata hasil belajar siswa adalah 79,9 dengan persentase ketuntasan belajar klasikal siswa telah mencapai $82,7 \%$.

Berikut grafik nilai akhir hasil belajar siswa tiap siklus:

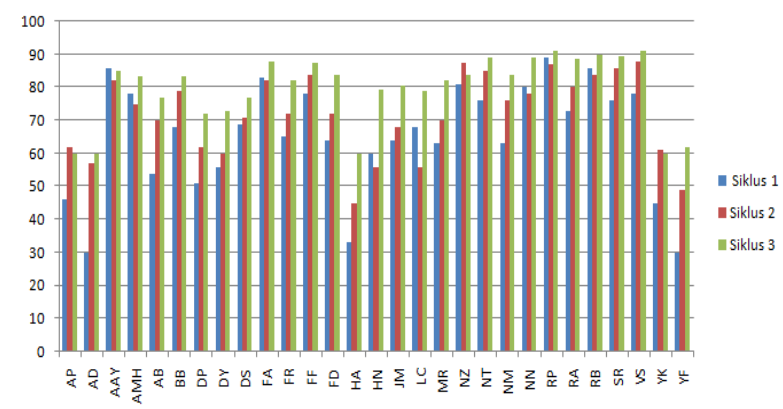

Grafik 4.5 Perbandingan nilai akhir hasil belajar siswa tiap siklus.

Berdasarkan grafik 4.5 terlihat bahwa nilai siswa tidak selalu naik meningkat disetiap siklus. Terdapat 18 siswa yang nilai akhir hasil belajar selalu meningkat dari siklus I sampai siklus III, dan 3 orang siswa nilainya meningkat pada siklus II tetapi turun pada siklus III. Sebanyak 8 siswa yang mendapatkan nilai hasil belajar turun pada siklus II dan memperoleh peningkatan nilai pada siklus III. Grafik 4.5 juga menunjukkan ada 5 siswa yang nilainya tidak pernah mencapai KKM dengan 3 orang siswa tersebut meningkat nilai setiap siklus sedangkan nilai 2 siswa lainnya turun pada siklus III. Hal terjadi dikarenakan saat proses pembelajaran, siswa tersebut susah untuk diajak bekerja sama, asik mengrobrol tanpa mendengarkan apa yang sampaikan, menggangu teman satu kelompoknya dan tidak mendengarkan penjelasan guru serta tidak maunya bertanya mengenai materi yang tidak dipahami serta.

\section{B. PEMBAHASAN}

Analisis cara-cara meningkatkan Hasil belajar siswa

Pencapaian hasil belajar peserta didik kelas VIII F SMP Negeri 15 Kota Bengkulu dengan penerapan model cycle learning $5 E$ ditinjau dari rata-rata siawa maupun ketuntasan belajar klasikalnya. Untuk siklus I diperoleh rata-rat nilai hasil belajar 65,3 dengan ketuntasan 
belajar klasikal 48,3\% (belum tuntas). Rendahnya hasil belajar dan ketuntasan belajar klasikal siswa di siklus I dikarenakan siswa masih beradaptasi dengan proses belajar mengajar yang baru diterapkan. Hasil tes akhir siklus menunjukkan siswa yang tidak tuntas dikarenakan siswa belum memahami beberapa materi. Dimana dalam soal diminta untuk menggambarkan kerangka kubus dan balok serta menyebutkan unsur-unsurnya. Sekitar 10 orang siswa masih terlihat belum terlalu benar menjawab soal yang diberikan. Berikut salah satu contoh jawaban siswa:

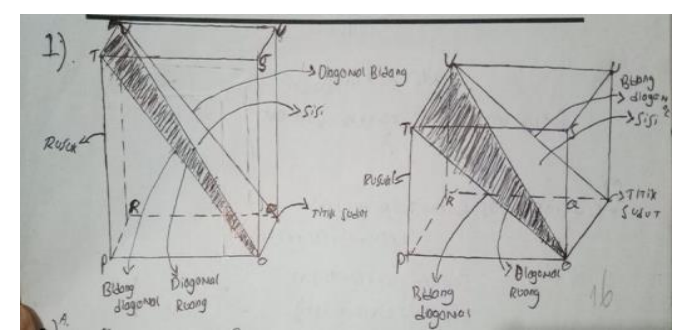

Gambar 4.60 Hasil jawaban siswa nomor 1 siklus I Gambar 4.60 memperlihatkan bahwa sebenarnya siswa sudah memahami maksud dan tujuan yang diinginkan pada soal. Siswa juga sudah dapat menggambarkan dengan cukup baik dan memahami mengenai unsurunsur kubus dan balok tersebut, tetapi hanya saja siswa masih keliru menunjukkan bagian bidang diaogonal dan diagonal ruang pada bangun ruang sisi datar kubus dan balok.

Selanjutnya soal mengenai luas permukaan, dimana meminta siswa untuk mencari tinggi suatu balok jika panjang, lebar dan luas permukaannya sudah diketahui. Sekitar 15 orang siswa masih salah dalam mengerjakannya. Berikut jawaban siswa :

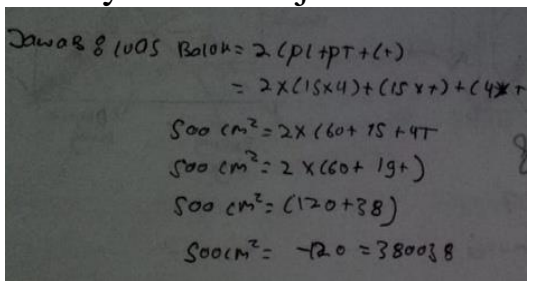

Gambar 4.62 Contoh jawaban siswa soal 5 tes siklus I

Berdasarkan jawaban salah satu siswa diatas nampak siswa masih salah mengerjakannya, ini disebabkan siswa kurang teliti dalam pengerjaannya. Kemudian juga ada siswa yang masih bingung, sehingga pengerjaannya hanya sampai setengah saja. Untuk soal-soal lainnya pada siklus I siswa tidak mengalami kesulitan dalam menyelesaikannnya hanya saja ada beberapa yang kurang memberikan satuannya saja. selain kesalahan yang dijelaskan diatas, penyebab lain dari hasil tes siklus yang belum mencapai KKM dikarenakan siswa belum aktif mengikuti kegiatan pembelajaran dan siswa masih belum percaya diri dengan kemampuan yang dimiliki serta takut untuk bertanya kepada guru jika belum memahami materi.

Tindakan perbaikan yang dilakukan guru adalah dengan menekankan siswa untuk dengan serius dan sungguh-sungguh dalam mengerjakan LAS secara kelompok maupun secara individu, kemudian juga meminta siswa jngan takut untuk bertanya apabila ada kesulitan setiap tahapnya.

Rata-rata hasil belajar siswa mengalami peningkatan disiklus II, yaitu 71,9 dengan ketuntasan belajar klasikal $63,1 \%$ (belum tuntas). Masalah siswa belum memperoleh nilai ketuntasan minimum masih menjadi perhatian peneliti. Pada pelaksanaan siklus II siswa sudah mulai terbiasa dengan proses pembelajaran menggunakan model pembelajaran cycle learning 5E. Secara keseluruhan siswa sudah dapat memahami maksud dari soal yang diberikan dan sudah dapat diselesai juga, tetapi ada juga siswa yang kurang teliti dalam mengerjakannya serta tidak menjawab soal sampai dengan selesai.

Faktor yang menyebabkan siswa belum mencapai nilai KKM disiklus II, yaitu kurang telitinya siswa saat melaksanakan proses penyelesaian masalah, kurang percaya dirinya dengan jawaban yang diperoleh sehingga menunggu jawaban teman yang membuat soal tidak terselesaikan.

Tindakan perbaikan yang dilakukan guru adalah dengan memberikan bimbingan kepada siswa yang kesulitan saat proses pembelajaran kelompok dan menekankan kepada siswa untuk lebih teliti serta memeriksa kembali hasil yang dikerjakan sebelum dikumpulkan, serta memberikan teguran keras kepada siswa yang masih mengandalkan teman. 
Berdasarkan tes akhir siklus III terdapat 5 siswa yang masih mendapatkan nilai dibawah KKM. Faktor yang menyebabkannya antara lain dikarenakan siswa tersebut langsung menjawab tanpa membuat terlebih apa yang ditanya, apa yang diketahui, tidak membuat satuan, tidak semua soal dikerjakan, serta tidak serius dalam menjawab soal pada tes siklus III.

Hasil belajar siswa siklus III mengalami peningkatan, meskipun masih ada 5 siswa yang menjawab seperti gambar 4.63. rata-rata hasil belajar menjadi 79,7 dengan ketuntasan belajar klasikal $82,7 \%$ sehingga sudah memenuhi indikator keberhasilan yang ditetapkan. Berdasarkan nilai akhir siklus I, siklus II, siklus III tersebut menunjukkan jika proses pembelajaran dengan menerapkan model pembelajaran cycle learning $5 E$ dapat meningkatkan hasil belajar siswa kelas VIII $\mathrm{F}$ SMP Negeri 15 Kota Bengkulu.

\section{PENUTUP}

\section{A. Simpulan}

Penerapan model pembelajaran cycle learning $5 E$ dapat meningkatkan hasil belajar siswa dengan :

a. Memberikan pertanyaan-pertanyaan untuk membantu peserta didik menyelesaikan permasalahan yang diberikan, sehingga siswa bukan hanya menghafal rumus, tetapi memahaminya.

b. Memberikan kesempatan pada peserta didik untuk menanyakan hal-hal yang belum mereka pahami saat proses belajar mengajar berlangsung.

c. Melakukan pembentukan kelompok dengan anggota 4 orang siswa dalam satu kelompok agar siswa berkesempatan berbagi informasi dalam belajar.

d. Guru memaksimalkan aktivitas belajar siswa pada tiap tahapan Cycle Learning $5 E$, terutama pada tahap exploration dengan cara menggunakan media alat peraga dan pada tahap elaboration membantu siswa yang kesulitan saat proses pembelajaran.

e. Memberikan soal latihan pada tahap evaluation sehingga pemahaman siswa terhadap materi lebih mendalam serta selalu mengkoreksi ulang hasil pekerjaanya sebelum dikumpulkan.

Hasilnya pada siklus I, nilai rata-rata siswa adalah 65,3 dengan ketuntasan belajar klasikal $48,3 \%$. Pada siklus II jumlah siswa yang tuntas meningkat dan rata-rata siswa pun meningkat menjadi 71,9 dengan ketuntasan belajar klasikal 63,4\%. Pada siklus III rata-rata siswa meningkat lagi menjadi 79,7 dengan ketuntasan belajar klasikan $82,7 \%$.

\section{B. Saran}

Berdasarkan penelitian yang telah dilakukan, maka peneliti memberikan beberapa saran, yaitu :

1. Penggunaan waktu dalam penerapan model Cycle Learning $5 E$ harus diperhatikan agar semua aktivitas dan tujuan pembelajaran tersampaikan, hal ini dilakukan dengan cara selalu mengingatkan siswa pada setiap kegiatan pembelajaran sehingga siswa tidak menghabiskan banyak waktu pada satu kegiatan saja.

2. Pemberian motivasi dan bimbingan harus dilakukan dalam setiap tahapan model Cycle Learning $5 E$ agar siswa terdorong untuk aktif selama kegiatan pembelajaran, terutama pada tahap exploration dan elaboration.

3. Mengulang kembali materi yang belum siswa dimengerti sebelum memulai tes siklus.

\section{DAFTAR PUSTAKA}

Aunurrahman. 2012. Belajar dan Pembelajaran. Bandung: Alfabeta.

Huda, Miftahul. 2014. Model- model pengajaran dan pembelajaran. Yogyakarta: Pustaka Pelajar.

Huda, Miftahul. 2014. Model- model pengajaran dan pembelajaran.

Yogyakarta: Pustaka Pelajar. 
Lestari, eka \& Yudhanegara, ridwan. 2015. Penelitian pendidikan matematika. Bandung: PT. Refika Aditama.

Priyanto, Agus. 2013. Penerapan Model Learning Cycle $5 E$ Untuk Meningkatkan Aktivitas dan Hasil Belajar Siswa Kelas VII SMP Negeri 5 Kota Bengkulu. Bengkulu. Universitas Bengkulu.
Sudjana, Nana. 2016. Penilaian Hasil Proses Belajar Mengajar. Bandung: PT RemajaRosdakarya. 